Kants Theorie der Biologie: Ein Kommentar. Eine Lesart. Eine historische Einordnung, by Ina Goy, Berlin: De Gruyter, 2017, 420 pp., 109.95€ (hb), ISBN 3110471108.

\title{
Introduction
}

Ina Goy's Kants Theorie der Biologie (KTB) is a landmark text, providing the first systematic account of Kant's extensive reflections on organized beings. It is comprehensive in scope, displaying a remarkable attention to textual detail while maintaining a systematic view of the critical project. As a whole the book offers a reference text for scholars interested in the dense and often confusing argument of Part 2 of the third Critique, the Critique of the Teleological Power of Judgment. 115 of its 420 pages are dedicated to a line-by-line exposition of the relevant sections. It is thus well placed to legitimate and extend the growing body of work on Kant's account of the life sciences. However, KTB is first and foremost an expository text; it does not put to bed those who are skeptical about Kant's so-called 'biology'.

There are several reasons that Kant's account of organized beings has been hitherto neglected. In Metaphysical Foundations Kant sets a high bar for proper science: it must be 'systematic', constitute an 'interconnection of grounds and consequences', and provide 'apodictic' certainty (MF 4:468). Only mathematics and physics can meet the mark, while forms of empirical inquiry such as chemistry and the life sciences are improper, for they 'carry with them no consciousness of their necessity'. The problem is that a priori principles provide no guarantee that appearances are anything more than a 'labyrinth of the multiplicity of possible empirical laws' (FI 20:214). This is to say that the understanding has no grounds to expect that nature hangs together as a system. Those who have tried to salvage Kant's account of living beings as a scientific enterprise, following Timothy Lenoir (1982), have been highly criticized on two fronts: for projecting contemporary problems onto Kant (Richards 2000), and, more seriously, for denaturalising biology (Zammito 2006).

Despite the title, Goy's book does not directly address the question of Kant and biology. Her argument instead aims to ground Kant's theory of organized beings not as a proper science but as the key to completing the critical system of knowledge. To this end Goy opens with Kant's three famous questions, 'What can I know? What ought I to do? What may I hope?' (CPR A805/B833). 'Kant does not simply answer these three questions in the Religion,' she claims, for 'he first and foremost answers them in the three Critiques' (KTB Vorwort). As Kant mentions in the first Critique, the third question is particularly important to the system of critical philosophy, for it concerns 'the practical and the theoretical together' (CPR A805/B833). Yet it is for that reason the most difficult to answer. Goy's claim is that the question of hope is not simply a matter of religion, to be found in the idea future rewards. Rather, Kant's project in the Critique of the Power of Judgment, and especially in his theory 
of organized beings, aims to provide an answer in this world. The beauty and organization we discover in nature demonstrates nature's purposive form in such a way that harmonizes the practical and theoretical spheres. While plants, animals, and humans themselves feature as objects of the understanding, Kant aims to show that they also feature as purposive objects of nature to the extent that they realize the law of freedom in nature. The embedment of purposive form 'allows humanity to hope that the purposive form that produces itself in nature can satisfy the demand of pure practical reason' (KTB Vorwort). Thus 'the world, in which humans are able to think of themselves as a free and rational beings, and nature, in which humans live and play the role of law-governed, natural beings, cease to fall apart.' Biology might not be a proper science, but it confirms and grounds the critical system.

Goy's reconstruction of Kant's theory of biology falls into three parts: a commentary, an interpretation, and a historical classification. I will consider these briefly in the following.

\section{A commentary}

The first part of the book (Ein Kommentar) provides a 'summary of each text up to 1790 in which Kant develops a theory of organized beings or part of such a theory' (KTB 3). The comprehensiveness of Goy's work is quite stunning, if not a little overburdened; she works though 'Universal Natural History', the 'Argument' essay, Kant's three essays on race, the review of Herder's 'Ideen', Metaphysical Foundations, the passages on teleology in the first and second Critiques, Kant's 'Theological Principles' essay, and - most extensively the Critique of the Power of Judgment. While the second part of the third Critique, the Critique of the Teleological Power of Judgment, is often viewed as a surprising addition to the critical program, summarizing Kant's rather eclectic fusion of epigenesis and preformationism, Goy shows that the teleological investigation of living things is native to Kant's voluminous project, both predating and enduring beyond the so-called critical turn of 1781. While Kant employs a teleological method in 'Universal natural history', it is 'from 1775 [that] the analysis of the emergent principles of organizing beings enters more strongly in the foreground' (KTB 4). As Kant examines the historical claims made by natural historians in the domain 'where theory abandons us', as Kant puts it in 'Teleological Principles' (TP 8:157), he searches for a method analogous to that used in the physical sciences. His struggle to elaborate a theory of human development, the progress of his critical epistemology, his encounter with Herder in the mid-1780s, and his critical examination of teleological judgment work together to reveal what Goy labels 'Kant's theory of organized beings' (KTB 1).

In the bulk of this part, Goy provides a detailed commentary of the introduction and the 'Analytic' (§§61-8), 'Dialectic' (§§69-78), and 'Doctrine of Method' (§§79-91) of the Critique of the Teleological Power of Judgment. In the 'Analytic' Kant describes organized 
nature, which, according to Goy, is characterized through two forms of law: 'the mechanical and the physical-teleological' (KTB 138). In the 'Dialectic' Kant presents organized nature in such a way that 'the empirical manifold can be explained through both forms of powers and laws of nature, without both forms of power and laws of nature becoming caught in a contradiction.' While many studies of Kant's biology skip over the 'Doctrine of Method', Goy examines it as the capstone of both the third Critique and the critical project as such. Teleological judgment invites and also requires an expansive view of nature that includes a form of the physicotheological and moral proofs for das Dasein Gottes (KTB 183). Against those who try to naturalize Kant's biology, Goy contends that only by uniting the different perspectives evoked in the 'Analytic' and the 'Dialectic' in the representation of a divine intellect can we coherently account for organized beings, drawing the theoretical and practical perspectives of rational beings into a unified experience of nature.

\section{An interpretation}

In the second part of the book (Eine Lesart), Goy moves from a textual to a systematic reading of Kant's theory of organized beings. She proposes six theses, which I will simply list here for the sake of brevity. From 'the perspective of the human power of judgment', organized beings are

1. machines, for they consist of mechanical movements and alterations that fall under mechanical powers and laws (2.1)

2. physical-teleological beings, for their mechanical movements and alterations are directed toward the fulfillment of natural purposes (2.2)

3. moral-teleological beings, for the various natural ends find their ultimate unity in moral purposes (2.3)

The first three perspectives of organized beings can be summarized as mechanical, physicalteleological, and moral-teleological. Yet the application of these three ways of viewing the powers and laws governing organized beings begs the question of their agreement. This opens a new line of inquiry for Kant. The human idea of organized beings allows for belief in the regulative idea of God and God's creation, for only a non-human consciousness could represent and produce their unity. Thus the human power of judgment allows for three further perspectives: organized beings

4. are characterized by mechanical and physical-teleological powers and laws of nature (2.5)

5. are characterized by physical- and moral-teleological powers and laws (2.5) 
6. allow humans to believe in a regulative idea of God; a God who represents the unity of the powers and laws of nature and morality and thereby grounds their compatibility for the human perspective (2.7)

While the first three theses characterize organized beings from 'the human standpoint', the second three characterize organized beings from 'a humanly possible representation of a divine standpoint and the unity of a divine order' (KTB 188). By emphasizing the theological implications of Kant's theory of biology, Goy is critical of Hannah Ginsborg's (2014) influential reading of the third Critique in terms of 'primitive normativity', a normativity that can be derived simply from the free play of the human faculties. For Goy, Ginsborg's reading removes Kant's theory from its theological bedding, undermining the critical and regulative status of organization. Goy is also critical of Angela Breitenbach's $(2009,85)$ reading of organized beings as understood through 'an analogy with our own reason', for it leaves 'undeveloped' the unity of the different powers and laws of nature, and the unity of the different powers and morality (KTB 190). Her reading is much closer to scholars such as Rachael Zuckert (2007), Paul Guyer (2005) and John Zammito (1992), who recognize the moral-teleological dimension of Kant's theory.

\section{A historical classification}

In the third part (Eine historische Einordnung) Goy outlines the 'systematic relationships between Kant's theory of organized beings and historical currents in the natural science of the $17^{\text {th }}$ and $18^{\text {th }}$ centuries' (KTB 287). Again following her rigorously systematic approach, Goy works through the ovist and animalculist forms of preformationism, mechanical and vital epigenesis, and the many systems of classification advanced by the likes of Harvey, Linnaeus, Buffon, Maupertuis, Wolff, and Blumenbach. Her argument in this part is that 'one can understand Kant's position as a weak (critical, regulative, interpretive) theory of preformationism', for he works with the 'regulative idea of a creation in a material and formal sense'. Critical epistemology simply does not grant a stronger theory of a formative, vital power. Goy's account covers familiar terrain, and yet is comprehensive and extremely helpful in understanding the motivation behind Kant's theory. Her argument that Kant's notion of the 'formative power' or Bildungsteib is taken not simply from Blumenbach but also from Wolff is compelling, developing a richer account than that begun in Goy (2014).

Against standard classifications, which place Kant in the vitalist (Zumbach 1984) or vital materialist (Huneman 2006, Zammito 2003) camps, Goy carefully works through Kant's many works to show that his position is not so easily pinned down. Kant represents preformationism as much as epigenesis, Goy claims (KTB 347), which provides further evidence for her six theses outlined in Part 2. Kant grants to the life sciences an epigenetic 
power and epigenetic laws 'insofar as he describes a formative power and physicalteleological laws, which create the purposive form of matter, and cause the automatic production (not simply cloning or developing) of the species called into life by God, the production and preservation of individuals in a species, and the parts of individuals' (KTB 384). Generation for Kant is thus both genuine and yet the result of 'the idea of God in the beginning and the idea of God as the highest purpose at the end of creation.' His theory of germs and natural endowments retains this element of preformationism, especially in his essays on race, and yet his account of generation, particularly in the third Critique, entails a robust account of production. Goy contends that these two moments of Kant's thought can only be maintained if we interpret Kant through her six theses, which subordinate formative powers and physical-teleological laws to divine ends.

\section{Concluding remarks}

The controversial claim of Goy's book is that Kant has a theory of biology at all. Yet she does not provide this claim with an explicit defense. From the outset she recognizes that 'Kant wrote about organized beings in a time when biology as a scientific discipline was not yet established under its own name' (KTB 5). The investigation of living beings in Kant's time covered a range of 'academic disciplines, including natural history and the description of nature, physiology, physics, medicine, anatomy and theology.' Yet by naming Kant's theory of organized beings a theory of biology, one is left wondering how Kant's difficult and unique account of organization is related to the subsequent history of biology opened by Treviranus and exploded by Darwin. Goy's reading certainly provides evidence against the view that Kant's theory anticipated a constitutive account of generation (Lenoir 1982) or that it can be naturalized (Wood 1999). Yet its implications for contemporary debates about function and purpose in contemporary biology remains unexplored. Goy's concern for Kant's theory of organized beings overlooks recent interest in Kant's notion of a 'research program' (Butts 1990, Kitcher 1986). Did Kant's theory hamper or enable the biological research undertaken by the Göttingen School and the German vital materialists of the $19^{\text {th }}$ century? Can Kant's account shed light on current controversies in the philosophy of biology? A good deal of ink has been spilled over these questions, and the strength of $K T B$ lies in its capacity to guide and inspire future work along textually rigorous lines. I have heard that Goy intends to work on an English translation in the near future. For the sake of advancing this conversation in the Anglophone world with the help of Goy's rigor, I hope that it comes in the not-too-distant future. 


\section{References}

Abbreviations of Kant's works cited above:

CPR Critique of Pure Reason. Translated by P. Guyer \& A. Wood. Cambridge: Cambridge University Press, 1999.

MF Metaphysical Foundations of Natural Science. Trans. \& ed. M. Friedman. Cambridge: Cambridge University Press, 2004.

$\mathrm{TP}$

'On the use of teleological principles in philosophy.' In Anthropology, History, and Education, G. Zöller and R. Louden (eds.), Cambridge: Cambridge University Press, 2007, 195-218.

FI 'First Introduction to Critique of the Power of Judgment.' Translated by P. Guyer. Cambridge: Cambridge University Press, 2000.

CPJ Critique of the Power of Judgment. Translated by P. Guyer. Cambridge: Cambridge University Press, 2000.

Secondary sources:

Breitenbach, Angela. 2006, Die Analogie von Vernunft und Natur. Ansatz zu einer Umweltphilosophie nach Kant, Berlin/New York: De Gruyter.

Butts, Robert. 1990. 'Teleology and Scientific Method in Kant's Critique of Judgment.' Noûs 24: $1-16$.

Ginsborg, Hannah. 2014. The Normativity of Nature. Oxford: Oxford University Press.

Goy, Ina. 2014. 'Epigenetic Theories: Caspar Friedrich Wolff and Immanuel Kant.' In Goy, Ina \& Watkins, Eric (eds.). Kant's Theory of Biology. Berlin: De Gruyter: 43-60.

Guyer, Paul. 2005. Kant's System of Nature and Freedom: Selected Essays (Oxford: Oxford University Press).

Kitcher, Philip. (1986) 'Projecting the Order of Nature.' In Robert Butts (ed.), Kant's Philosophy of Physical Science. Dordrecht: D. Reidel Publishing Company: 201-238.

Lenoir, Timothy. 1982. The Strategy of Life: Teleology and Mechanics in Nineteenth-Century Biology, Dorgrecht, Holland: D. Reidel.

Richards, Robert. 2000, 'Kant and Blumenbach on the Bildungstrieb,' History of Biological and Biomedical Sciences, 31, 11-32.

Wood, Alan. 1999. Kant's Ethical Thought. Cambridge: Cambridge University Press.

Zammito, John. 1992. The Genesis of Kant's Critique of Judgment. Chicago: The University of Chicago Press.

Zammito, J., 2006, 'Teleology then and now,' History of Biological and Biomedical Sciences, $37,748-770$. 
Zuckert, Rachael. 2007. Kant on Beauty and Biology. Cambridge: Cambridge University Press.

Zumbach, Clark. 1984. The Transcendent Science: Kant's Conception of Biological Methodology. The Hague: Nijhoff. 